\title{
The Relationship between Self-Regulated Learning and Mathematics Attitude towards College Students Development of Mathematical Thinking
}

\author{
Parmjit Singh 1,*, Muhammad Amirul Afiq B Abd Moin, Palanisamy K. Veloo², \\ Cheong Tau Han ${ }^{1}$, Teoh Sian Hoon ${ }^{1}$ \\ ${ }^{1}$ Faculty of Education, Universiti Teknologi MARA Selangor, Malaysia \\ ${ }^{2}$ SEGI University, Kuala Lumpur, Malaysia
}

Received June 28, 2019; Revised September 5, 2019; Accepted September 12, 2019

Copyright $\subseteq 2019$ by authors, all rights reserved. Authors agree that this article remains permanently open access under the terms of the Creative Commons Attribution License 4.0 International License

\begin{abstract}
College students, especially those majoring in STEM related fields do take fairly large numbers of mathematical courses as part of their tertiary requirement and do indeed construct a variety of numerous algorithms in order to continue to achieve good results in their examination transcripts. However, what is the quality of this mathematical knowledge in relation to their mathematical thinking development? Secondly, does self-regulated learning (SRL) and the attitude formed towards math learning bear a significant correlation to the achievement of students' in mathematics. Based on these questions, a total of one hundred and sixty-four randomly selected final year undergraduates majoring in Science field were involved in this descriptive-correlational design study. The research findings depict that solving some of the most fundamental and basic math problems served as an obstacle to the college students. Students seem to rely a great deal on the numerical computation aspect, notwithstanding that this confers an adverse effect upon their abilities to think and perform problem solving operations. The findings also portray an absence of a significant relationship between the student's self-regulated learning and the attitude towards mathematical thinking attainment. This showcases that whilst students are perceived to have the ability to direct their learning process and do have fun in the math classroom, this has not translated into their cognitive processes in developing their mathematical thinking.
\end{abstract}

Keywords Mathematical Thinking, Achievement, College Mathematics, Self-Regulated Learning, Attitude

\section{Introduction}

One of the major aims of mathematical learning is to usher the development of mathematical thinking with an intention to mould one's mind into thinking systematically and analytically in solving problems and making decisions [1] - [3] for real life application. Through meaningful learning, an inquisitive mind-set accompanied by a passionate curiosity to solve problems tends to lead students to think critically whilst creating possible solutions of the problem. This philosophy struts in tandem to the Malaysian education policy, which is to cultivate and develop the ability of students to encourage meaningful learning and triggering mental challenges, with the aim of furnishing all-rounded and holistically developed individuals [4]. At this juncture, it is worth asking whether or not this aspired philosophy in the teaching and learning of mathematics has affected the current setting as per the Malaysian 21st century paradigm.

At the very beginning itself, it would be useful to address a fairly common misconception etched in the minds of many people, and so it suffices to express that "mathematical thinking" in comparison to "doing mathematics" involves a wholly different ball game altogether. This misconception stems from the pedantic mathematics education in our systems which highlight the mastery of mathematics through rote memorization of formulaic structures. The consequential impact is negatively felt when such an approach is no longer viable and usable at a higher level of tertiary education. From such inferences, one could gather the glaring disparity existing between the mathematics subject as taught in schools, following somewhat rigid, hard and fast rules and formulaic approaches and at the other end of the spectrum what could be labelled as the real mathematical thinking, 
involving thinking 'outside of the box.' Clearly, it is the latter that would carries more weight and value in the long run amongst university students and professionals as well. Rallying to such an argument, there is a widespread agreement that mathematics should be taught as a thinking activity ([2], [3]). What then, is the quality of this mathematical knowledge in relation to college students' mathematical thinking development at the present time?

Self-regulated learning is defined as the ability to control the cognitive, metacognitive and behavioural aspects of one's learning ([5], [6]) where emphasis was placed on strategies and plans developed by the learner in order to direct their learning behaviours. Another variable of interest that is commonly related to student's achievement in mathematics is their attitude towards mathematics learning ([7], [8]). Having enjoyment and pleasure as a part of the learning process plays a major role in striving for the aim stipulated earlier, consequently contributing attaining better grades. Nevertheless, do they serve to predict the development of mathematical thinking amongst college students? Thus, the objectives of this study are:

1. To examine the level of students' self-regulated learning, attitude towards mathematics and their attainment in mathematical thinking.

2. To investigate whether the students' self-regulated learning and attitude towards mathematics are a reliable factor in predicting their attainment in mathematical thinking.

\section{Literature Review}

The purpose of learning mathematics in higher education is to facilitate cognitive enhancement and to provide in-depth knowledge where mathematical thinking is concerned. Mathematical thinking is defined as a thinking behaviour directed by the cognitive process in the learning of mathematics [2]. Such thinking is pre-built in the mind of an individual when solving math problems. According to [3], "thinking mathematically is about developing habits of mind that are always there when you need them - not in a book you can look up later (p. 1). Unfortunately, however, the findings of some studies carried out within the local domain, though nothing new, it came across as rather disappointing. For instance, (i) most students despite scoring A's in year-end math examinations lacked a substantive concept of thinking ([9], [10], [11]). (ii) Most of the instructors on the delivering end of the spectrum appear to be in denial, not realizing that they lack in terms of the substance of the concept and hold the belief that they have grasped critical thinking well enough to teach it within their means [12]. (iii) Although various measures have been adopted in bringing about reformation, it is unfortunate that some of the older teaching methods such as rote memorization and other strategies that could only serve a short term purpose in mathematics education still take precedence in the classroom environment till date ([9], [13], [14]). In the study by [9], two fundamental differences of a task in differentiating between routine and non-routine math problem in assessing students mathematical thinking development formed the subject of discussion (refer figure 1 and 2).

a) Find the area of the right angle triangle in figure 1 (routine problem).

b) Find the area of the right angle isosceles triangle in figure 2 without the aid of Pythagoras or trigonometry functions (non-routine problem).

Their finding reveals only $15 \%$ of the high school students (as compared to $98 \%$ success rate for item in figure 1) were able to solve the problem without the aid of Pythagoras or trigonometry functions. Regardless of the fact that mathematical learning has been ongoing for a significantly long duration (from primary, secondary to university), many research studies have shown that learners have a dearth of key cognitive strategies and lack confidence, as well aptitude in approaching non-routine mathematical related problems [15] What then, is the quality of this mathematical knowledge in relation to their mathematical thinking development at the present time?

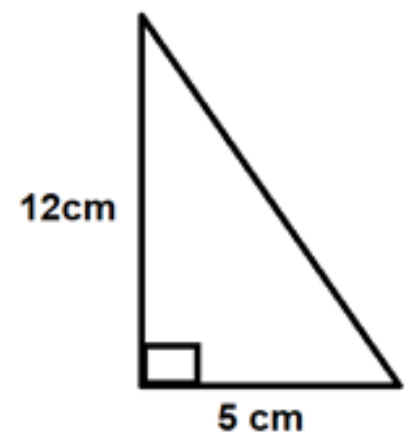

Figure 1. Routine Problem

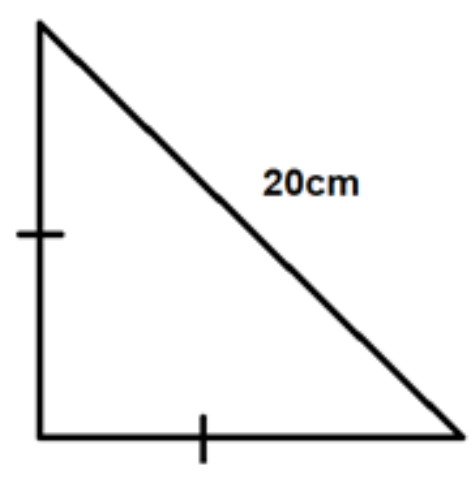

Figure 2. Non-routine Problem

The other two variables of interest for this study are self-regulated learning and the attitude taken towards mathematics. According to [6], self-regulated learning is constrained and guided by contextual features of the environment as well as by the personal characteristics of learners themselves. He stressed that the importance of 
self-regulated learning is "being strategic" rather than only "having"' one or more strategy. It is one thing to be able to recognize one's own strategy and it is quite a different thing to be liable to use it and adapt it at various task orientations [6]. Various researches revealed that self-regulatory strategy usage is positively associated with academic performance at different levels of education.

How one perceives the subject of mathematics, in the form of general feelings as well as beliefs shared on it reflects the attitude taken towards it [8]. It demonstrates how the students' behave towards mathematics and the achievement that would contribute in the students' motivation and inspiration in learning mathematics [16]. Adopting a positive attitude towards mathematics has always been said to be strongly related to academic performance. However, some recent findings have depicted a contrast from previous studies as elucidated above. A study by [17] on high school students found no significant relationship between attitude and mathematics achievement. Coherently, findings from other researches strut in tandem, portraying no connection between what one achieves in the subject of mathematics, and any beliefs held relating to it ([18], [19]). Furthermore, in the recent TIMSS (Trends in Mathematics and Science Study) conducted in 2015, a similarly story of the low correlation between achievement and confidence towards mathematics was depicted. As shown in table 1, Hong Kong, Singapore and Japan were among the top five achievers in the study, however, the low correlation coefficient among these two variables were $0.38,0.40$ and 0.47 . In other words, only $14 \%, 16 \%$ and $22 \%$ of confidence can be attributed to student achievement and vice versa. The question is- could the same be said with regard to mathematics learning at the college/university level?

Table 1. Relationship between the TIMSS Students' Confidence in Mathematics Scale and TIMSS Mathematics Achievement

\begin{tabular}{|c|c|c|}
\hline \multicolumn{3}{|c|}{$\begin{array}{c}\text { Relationship Students Confident in Mathematics and Mathematics } \\
\text { Achievement }\end{array}$} \\
\hline Country & $\mathrm{r}$ & $\mathrm{r}^{2}$ \\
\hline Hong Kong & 0.38 & 0.14 \\
\hline Singapore & 0.40 & 0.16 \\
\hline Japan & 0.47 & 0.22 \\
\hline
\end{tabular}

Source:

http://timssandpirls.bc.edu/timss2015/international-results/timss-2015/m athematics/student-engagement-and-attitudes/students-confident-in-math ematics/

\section{Research Methodology}

This study adopted a quantitative method utilizing a descriptive-correlational design. This design enables researchers to determine the relationship between the latent variables of this study namely self-regulated learning, mathematics attitudes and students' attainment in the mathematical thinking test. It also accumulates evidence regarding the nature of college students' understanding of fundamental mathematical concepts in problem solving and some critical factors to be taken into account in facilitating their mathematical thinking development. The population for this study comprises final year undergraduate students enrolled in the Science degree courses (majoring in Mathematics, Physics, Chemistry and Biology) at a public university in Klang Valley, Malaysia. A total of one hundred sixty-four randomly selected final year undergraduates majoring in Science were involved in the study.

In total, three instruments were used in this study. The students' self-regulated learning instrument towards mathematics was adopted from the Motivated Strategies for Learning Questionnaire (MSLQ) by [20] that consists of 36 items. Meanwhile, the mathematics attitudes instrument that consists of 40 items was adopted from Attitudes towards Mathematics Inventory (ATMI) developed by [21]. The final instrument was the mathematical thinking test (MTT) adopted from [9] that comprised 15 problem solving items. Among the items included in the test includes:

- If it takes six men to paint a house in 21 days, how many men will be needed to paint the house in 14 days?

- $\quad$ Find the sum of all the NUMBERS in the sequence 1 $-2+3-4+5 \ldots-98+99-100$

- What is the next term for $8,18,36,49, \ldots$ ?

- Aiman can fill 10 buckets of water in 5 minutes. Borhan can fill 5 buckets of water in 10 minutes. Working together, how many buckets of water can they fill in 30 minutes?

Although these instruments were adapted, the rigour process of validity and reliability was carried for each of the instruments employed for the study. Thus, in this study, the instruments content validity was established by three content experts (for each of the instrument) from universities located at Klang Valley. On the other hand, the reliability coefficient of Cronbach's alpha test was employed for the MSLQ and ATMI while a test-retest reliability analysis was conducted for the MTT. Both the MSLQ and ATMI instruments yield high Cronbach's alpha coefficient of 0.93 and 0.96 respectively while the Test-retest reliability correlation for the MTT yielded a high coefficient of 0.93 . Thus, the researchers concluded that all three instruments were greatly valid and reliable to be used in this research as the measurement tools.

\section{Results}

This section details the findings of the study based on the research questions posed.

Research Question1: What is the level of student's attainment in the Mathematical Thinking test?

Table 2 depicts the mean score obtained by students in 
the mathematical thinking test is $18.30(\mathrm{SD}=8.45)$ out of a maximum score of 60 . In terms of percentage, the score obtained by the students is $30.5 \%$ [18.30/60 x 100\%]. Therefore, it can be concluded that the college students' attainment in the mathematical thinking test were extremely low. This is especially so since the students involved were final year undergraduate students majoring in Sciences.

Table 2. Descriptive of Mathematical Thinking Test Score

\begin{tabular}{|c|c|c|c|c|}
\hline Test & $\mathrm{N}$ & Mean & SD & Percentage (\%) \\
\hline MTT & 164 & 18.30 & 4.67 & $30.5 \%$ \\
\hline
\end{tabular}

Max Score-60

Research Question2: What is the level of students' self-regulated learning towards mathematics in: a) study skills? b) peer help? c) metacognitive self-regulation? d) environment (time and study management)? e) effort regulation? f) overall?

Table 3. Self Regulated Learning

\begin{tabular}{|c|c|c|}
\hline Construct & Mean & $\begin{array}{c}\text { Standard } \\
\text { Deviation }\end{array}$ \\
\hline Study Skills & 7.58 & 1.01 \\
\hline Peer Help & 7.52 & 1.03 \\
\hline Metacognitive Self-Regulation & 7.28 & 1.10 \\
\hline $\begin{array}{c}\text { Environment (Time and Study } \\
\text { Management }\end{array}$ & 7.48 & 1.15 \\
\hline Effort Regulation & 7.33 & 1.28 \\
\hline Overall & 7.45 & 0.98 \\
\hline
\end{tabular}

Max score-10

Table 3 shows each of the constructs in self-regulated learning as captured through the survey. The highest mean score is obtained in the study skills construct $(\mathrm{M}=7.58, \mathrm{SD}$ $=1.01$ ) and this is followed by peer help with a mean score of 7.52 (SD = 1.03). On the other hand, the lowest mean score is for the metacognitive self-regulation and effort regulation constructs with mean score of $7.28(\mathrm{SD}=1.10)$ and $7.33(\mathrm{SD}=1.28)$ respectively. The overall mean score of $7.45(\mathrm{SD}=0.98)$ indicates that the students have a moderately high self-regulated learning towards mathematics.

Research Question3: What is the level of students' attitudes towards the learning of mathematics in: a) sense of security? b) enjoyment? c) value? d) motivation? e) overall?

Table 4 depicts students' attitude towards mathematics learning based on the constructs. The data indicates that the enjoyment towards math construct attains the highest mean score of 7.60 ( $\mathrm{SD}=1.46)$ and this is followed by the value of math construct with a mean score of $7.47(\mathrm{SD}=1.26)$. The sense of security construct that consists of the anxiety and confidence factor on the other hand obtained the lowest with a mean score of $5.34(\mathrm{SD}=1.06)$. The overall mean score of $6.40(\mathrm{SD}=0.92)$ depicts that the students possess a moderately positive attitude towards the learning of mathematics.

Table 4. The Mathematics Attitudes Constructs' Score ( $\mathrm{N}=164)$

\begin{tabular}{|c|c|c|}
\hline Construct & Mean & Standard Deviation \\
\hline Sense of Security & 5.34 & 1.06 \\
\hline Enjoyment & 7.60 & 1.46 \\
\hline Value & 7.47 & 1.26 \\
\hline Motivation & 6.77 & 1.19 \\
\hline Overall & 6.40 & 0.92 \\
\hline
\end{tabular}

Max score-10

The Relationship between Students' Mathematics Attitudes and Their Mathematical Thinking Test Score

Research Question4: Is there a significant relationship between students' attitudes towards the learning of mathematics and their attainment in the mathematical thinking test?

Table 4 tabulates the relationship between students' attitudes towards the learning of mathematics and their attainment in the mathematical thinking test. The results show there is no significant relationship between any constructs in the attitudes towards the learning of mathematics and the attainment in the mathematical thinking test except the sense of security construct that contains confidence and anxiety factors. It was found that this construct has a moderately low positive significant relationship $[\mathrm{r}=0.28, \mathrm{p}$-value $=0.01]$ with the mathematical thinking test score at the 0.05 level.

Table 5. Relationship between Math Attitude and Mathematical Thinking Attainment $(\mathrm{N}=164)$

\begin{tabular}{|c|c|c|}
\hline Math Attitude & & Math Thinking \\
\hline Sense of security & $\mathrm{r}=0.28$ & $\mathrm{p}$-value $=0.012$ \\
\hline (Confidence \& Anxiety) & $\mathrm{r}=0.10$ & $\mathrm{p}$-value $=0.393$ \\
\hline Enjoyment & $\mathrm{r}=0.05$ & $\mathrm{p}$-value $=0.661$ \\
\hline Value & $\mathrm{r}=0.13$ & $\mathrm{p}$-value $=0.255$ \\
\hline Motivation & $\mathrm{r}=0.22$ & $\mathrm{p}$-value $=0.072$ \\
\hline Overall
\end{tabular}

Table 6. Regression Analysis on Students' Mathematical Thinking Attainment

\begin{tabular}{|c|c|c|c|c|}
\hline $\begin{array}{c}\text { Correlation, } \\
\mathrm{R}\end{array}$ & $\mathrm{R}^{2}$ & $\begin{array}{c}\text { Adjuste } \\
\mathrm{r} \mathrm{R}^{2}\end{array}$ & $\mathrm{~F}$ & Sig, $\mathrm{p}$-value \\
\hline 0.22 & 0.05 & 0.02 & 1.926 & 0.15 \\
\hline
\end{tabular}

Table 5 and 6 depict the multiple regression analysis on the contribution of the students' self-regulated learning and mathematics attitudes towards the attainment in the mathematical thinking test. The coefficient of determination, $\mathrm{R}^{2}$ between those variables was 0.02 . This indicates that only $2 \%$ of the dependent variables can be predicted from both independent variables which were the students' self-regulated learning and mathematics attitudes. Using the enter method, the results revealed that the $\mathrm{p}$-value $=0.153$ associated with $\mathrm{F}=1.926$ exceeded the 0.05 level. This indicates that the independent variables 
cannot contribute to the dependent variable

Table 7. Multiple Regression Analysis on Students' Attainment in the Mathematical Thinking Test based on the Predictor

\begin{tabular}{|c|c|c|c|c|}
\hline Variables & $\begin{array}{c}\text { Unstandardized } \\
\text { Coefficient (B) }\end{array}$ & $\begin{array}{c}\text { Standardized. } \\
\text { Coefficient } \\
(\beta)\end{array}$ & $\mathrm{t}$ & $\begin{array}{c}\text { Sig, } \\
\text { p-value }\end{array}$ \\
\hline Constant & 5.535 & 0.697 & 0.488 & 0.993 \\
\hline $\begin{array}{c}\text { Self } \\
\text { Regulated } \\
\text { Learning }\end{array}$ & 0.009 & 0.001 & 0.008 & 0.089 \\
\hline $\begin{array}{c}\text { Mathematics } \\
\text { Attitude }\end{array}$ & 1.986 & 0.215 & 1.723 & 0.03 \\
\hline
\end{tabular}

As a conclusion, both students' self-regulated learning $(\mathrm{p}=.993)$ and mathematics attitude $(\mathrm{p}=.089)$ is not a predictor and did not contribute to their attainment in mathematical thinking test.

\section{Discussion}

The main purpose of this study was to examine the relationship between students' self-regulated learning and mathematics attitude towards their attainment in mathematical thinking test. The overall analysis suggests that students have a moderately high self-regulated learning towards mathematics $(\mathrm{M}=7.45, \mathrm{SD}=0.98)$. Similarly, the students also address themselves to acquire a moderately high positive attitude $(\mathrm{M}=6.40, \mathrm{SD}=0.92)$ towards the learning of mathematics. However, the regression analyses depict that these high and positive self-regulated learning and mathematics attitudes in learning mathematics were not congruent with the students' attainment in the mathematical thinking test.

Previous studies ([22], [23]) on mathematics achievement have focused on routine problems where one has to comply with a certain procedure in order to arrive at a solution. [24] in his seminal study elucidated that merely solving routine problems plays close to no role in developing students mathematical thinking. On the other hand, non-routine problems help in shaping critical and creative thinking among students. These problems enable solvers to use different solutions and approaches in deciphering the problem [25]. Similarly, attitude was also not a good predictor for students' mathematical thinking attainment. These findings concur to previous researchers ([17], [18], [19]) where they found no relationship between attitudes and beliefs towards achievement in achievement. The contrast between the findings of this study and previous research may be explained by the mathematical thinking test used in this study where it tested the students' ability to think and reason mathematically without much reliance on computation and calculator usage. This should somewhat explain the mutual exclusiveness that exists between self-regulated learning and attitude with mathematical thinking development. While these findings certainly don't invalidate the predictive value of self regulated learning and math attitudes, [26] did suggest that one of the crucial reasons why those with higher general cognitive ability tend to do so well across so many learning situations is, in large part, their use of efficient learning strategies that maximize learning outcomes.

\section{Conclusions}

The nucleus of this study reveals that both self-regulated learning and mathematics attitude cannot be used to predict students' achievement in the mathematical thinking test. There is evidence from this study that these final year graduates majoring in Sciences have many of the same conceptual and reasoning difficulties that are common amongst high school students. Despite four long years of instruction in university level mathematics courses such as calculus, numerical analysis, real analysis etc., these courses fall inadequate, and students face a deficiency in terms of aptitude when it comes to tackling non-routine mathematical problems seeking to bring them out of their comfort zones [15]. Unfortunately, it comes across as such, that students have been rather fixated to successfully mastering numerical computations, notwithstanding that their thinking and problem solving abilities as well as anything else geared towards sharpening their mental faculties have taken a back seat in their journey of learning. From such observations, one could gather that a gap exists between mathematics courses undertaken at the university level stressing on rigid, hard and fast formulaic based approaches and that of actual mathematical thinking, which forces students to challenge their mental faculties and think out of the box. It is the latter that would serve a greater purpose where mathematical learning is concerned, be it amongst university students or even professionals for that matter. Providing appropriate systems, services and support for mathematical thinking should be a priority for HEIs. The high focus on the implementation of mathematics instruction based on the reasoning and understanding of mathematical knowledge will ensure their thinking develops. However, this can only happen with a paradigm shift on the nature of mathematics at HEIs.

\section{Acknowledgement}

This work was supported by University Teknologi MARA, Malaysia Grant Scheme (Project Number: CoRe82/T5/2015(17)/HDC(6))

\section{REFERENCES}

[1] Aida Suraya. (2015). Developing Students' Mathematical Thinking: How Far Have We Come? Retrieved July 15, 2018, from http://www.educ.upm.edu.my/dokumen/FKKD 


\section{I1_BULETINEDUC.pdf}

[2] Devlin, K. (2013). What is mathematics? Retrieved Aug 2, 2018, from http://crcrth650.wikispaces.umb.edu/file/view/ Devlin+-+Background_Reading.pdf

[3] Ridgway, J. (2009). Classroom assessment techniques mathematical thinking. Retrieved Aug 2, 2018, from www. flaguide. org/extra/download/cat/math/math/math. pdf.

[4] Ministry of Education Malaysia (MOE) (2013). Malaysia Education Blueprint 2013-2025. Putrajaya: MOE

[5] Zimmerman, B. J. (2002). Becoming a Self-Regulated Learner: An Overview. Theory into Practice, vol. 41, no. 2, pp .64-70, DOI: 10.1207/s15430421tip4102_2

[6] Pintrich, P. R. (2000). The role of goal orientation in self-regulated learning. In M. Boekaerts, P. Pintrich, \& M. Zeidner (Eds.), Handbook of self-regulation (pp. 452-502). San Diego, CA: Academic Press.

[7] Kalder, R.S. and Lesik, S.A. (2011). A classification of attitudes and beliefs towards mathematics for secondary mathematics pre service teachers and elementary pre service teachers: Issues in the Undergraduate Mathematics Preparation of School Teachers (IUMPST): The Journal. 5 (Teacher Attributes). www.k-12prep.math.ttu.edu

[8] Mcleod, D. B. (1992). Research on affect in mathematics education: a Reconceptualisation. In D. A. Grouws (Ed.), Handbook of Research on Mathematics Teaching and Learning (pp. 575-596). New York: MacMillan.

[9] Parmjit, S., \& Teoh, S. H. (2016). Islands of superficial knowledge without a canoe to get from one end to the other: The nature of college mathematics. International Journal on E-Learning and Higher Education, pp. 142-161.

[10] Noor Azina Ismail \& Halimah Awang, 2009. Mathematics achievement among Malaysian students: What can they learn from Singapore? International Education Studies, vol. 2, no. 1, pp. 8-17.

[11] Mohammadpour, I., Moradi, G. F., \& Najib Abdul Ghafar, M. 2009. Modeling Affecting Factors on Mathematics Performance for Singaporean Eight- Grades Students Based on Timss 2007. Paper Presented at the Proceedings of 2009 International Conference on Social Science and Humanities (ICSSH 2009), Singapore.

[12] Kuldas, S., Hashim, S., \& Ismail, H. N. (2015). Malaysian adolescent students' needs for enhancing thinking skills, counteracting risk factors and demonstrating academic resilience. International Journal of Adolescence and Youth, vol. 20, no. 1, pp. 32-47.

[13] Karadag, Z. (2009). Analyzing Students' Mathematical Thinking in Technology-Supported Environments. Retrieved July 17, 2018, from https://tspace.library.utoront o.ca/bitstream/1807/19128/1/Karadag_Zekeriya_200911_P hD_thesis.pdf

[14] Alton-Lee, A. (2003). Quality teaching for diverse students in schooling: Best evidence synthesis. Retrieved July 27, 2018, from http://thehub.superu.govt.nz/sites/default/files/ 42450_Quality-Teaching-2005_0.pdf

[15] Asman, D., Markowitz, Z. (2001). The Use of Real Word Knowledge in Solving Mathematical Problems” Proceedings of the 25th Conference of the International
Group for the Psychology of Mathematics Education, Utrecht, Netherlands.

[16] Tezer, M. (2010). Attitudes of primary school 2nd and 3rd grade students towards mathematics course. Procedia-Social and Behavioral Sciences, vol. 2, no. 2, pp. 5808-5812.

[17] Sarwat Mubeen, Safia Saeed \& Manzoor Hussain Arif (2013). Journal Of Humanities And Social Science (JHSS), vol. 6 , no. 4, pp. 38-41.

[18] Papanastasiou, C. (2000). School, effects of attitudes and beliefs on mathematics achievement. Studies in Educational Evaluation, vol. 26, pp. 27 - 42.

[19] Fraser, B., \& Butts, W. L. (1982). Relationship between perceived levels of classroom individualization and science-related attitudes. Journal of Research in Science Teaching, vol. 19, pp. $143-154$.

[20] Cynthia D. Otts (2010). Self-Regulation And Math Attitudes: Effects On Academic Performance In Developmental Math Courses At A Community College. Retrieved July 27, 2018, from http://citeseerx.ist.psu.edu/v iewdoc/download?doi=10.1.1.919.9444\&rep=rep1\&type= pdf

[21] Tapia, M., \& Marsh, G. E. (2004). An instrument to measure mathematics attitudes. Academic Exchange Quarterly, vol. 8, no. 2, pp. 16-22.

[22] Kilman, T. A. (2015). The relationship between students' applied mathematics skills and students' attitudes towards mathematics. . Dissertations(54). Retrieved July 28, 2018, from http://aquila.usm.edu/cgi/viewcontent.cgi?article $=10$ $57 \&$ context $=$ dissertations

[23] Kargar, M., Tarmizi, R. A., \& Bayat, S. (2010). Relationship between thinking, mathematics anxiety and mathematics attitudes among university students. Procedia Social and Behavioural Sciences, vol. 8, pp. 537-542

[24] Polya, G. (1981). Mathematics discovery: An understanding, learning, and teaching problem solving (combined edition). New York: John Willey \& Son.

[25] Mabilangan, R. A., Limjap, A. A., \& Belecina, R. R. (2011). Problem solving strategies of high school students on non-routine problems: A case study. Alipato: A Journal of Basic Education, vol. 5, pp. 23-46.

[26] Kaufman, S. B (2013). Learning Strategies Outperform IQ in Predicting Achievement. Retrieved July 28, 2018, from https://blogs.scientificamerican.com/beautiful-minds/learni ng-strategies-outperform-iq-in-predicting-achievement/ 